Woods, J. H., D. Kolotelo and A. D. YANChUK (1995): Early selection of coastal Douglas-fir in a farm-field test environment. Silvae Genet. 44: 178-186.

YAMADA, Y. (1962): Genotype by environment interaction and genetic correlation of the same trait under different environments. Jap. J. Genet. 37: 498-509.

YANCHUK, A. D. (1996): General and specific combining ability from disconnected partial diallels of coastal Douglas fir. Silvae Genet. 45: 37-44.

YEH, F. C. and J. C. HEAMAN (1987): Estimating genetic parameters of height growth in seven year-old coastal Douglas-fir from disconnected diallels. For. Sci. 33: 946-957.

Yeiser, J. L., W. Lowe and J. P. VAN BUIJTENEN (2001): Stability and seed movement for loblolly pine in the Western Gulf Region. Silvae Genet. 50: 81-88.
Yeiser, J. L., J. P. vAN BuiJtenen and W. J. Lowe (1981): Genotype $\mathrm{x}$ environment interactions and seed movement for loblolly pine in the Western Gulf Region. Silvae Genet. 36: 196-200.

XiANG, B. and B. Li (2001): A new mixed analytical method for genetic analysis of diallel data. Can. J. For. Res. 31: 2252-2259.

XIANG, B., B. Li and S. E. McKeand (2003a): Genetic gain and selection efficiency of loblolly pine in three geographic regions. For. Sci. 49: 196-208.

XIANG, B., B. LI and F. IsIK (2003b): Time trend of genetic parameters in growth traits of Pinus taeda L. Silvae Genet. 52: 114-121.

\title{
Genetic Variation in Reproductive Traits in a Clonal Seed Orchard of Prunus avium in Northern Spain
}

\author{
By R. DíAz ${ }^{*)}$ and E. MERLO \\ Departamento de Producción Forestal. Centro de Investigacións Ambientais de Lourizán, Apdo. 127, \\ Pontevedra, 36080 Spain
}

(Received $23^{\text {th }}$ October 2006)

\begin{abstract}
In the present study we investigated the reproductive phenology of Prunus avium in a seed orchard located in northwestern Spain. The study was carried out with 103 clones from 7 provenance regions in northern Spain. The most advanced flowering stage on different dates and the number of flowers and cherries were monitored over two consecutive years. Significant differences among clones were found for all of the studied traits, with high broad-sense heritability estimates for all, except duration of flowering and synchronization index, both of which showed moderate heritability. In general, there was good overall reproductive synchronization in the seed orchard, although two groups of clones were differentiated. Clones from two out of the seven populations studied flowered later and were less well synchronized. The clonal differentiation was correlated with geoclimatic variables, suggesting that clones from lower altitudes and higher temperatures tend to an earlier flowering.
\end{abstract}

Key words: Wild cherry, genetic variation, flowering, genetic parameters, reproductive synchronization, geographic pattern.

\section{Introduction}

Wild cherry is a very valuable forest tree species. The wood is mainly used for panelling and cabinet-making and achieves very high prices on the wood market. Breeding programmes have been initiated in several

\footnotetext{
*) Corresponding author: RAQUEL DÍAZ, Phone: +34-986805054, Fax: +34-986856420. E-mail: rdiaz.cifal@siam-cma.org
}

countries because of the value of the wood and the fast growth of the species (KoBLIHA, 2002). In Galicia (NW Spain) a long term breeding programme for this species was begun in the 1990's to improve timber quality and production. The breeding programme included phenotypic mass selection in wild stands and the use of the material for seed production in clonal seed orchards. Seed orchards are plantations created for production of genetically improved seeds to create commercial forest crops. The genetic quality of the seeds depends on the genetic superiority of the plus trees, their relationships, their combination ability, and the rate of pollen contamination, among other factors.

Variation in fertility and flowering phenology are generally known to affect the genetic composition of seed orchard crops (GöMÖRY et al., 2003). Thus, to improve tree quality it is important to investigate the variation in fertility and flowering phenology in seed orchards and to make predictions about the genetic composition of the seed crop. Significant genetic variation in flowering time has previously been reported for different Prunus spp. (Couranjou, 1995; DiCEnTA et al., 1993; Hansche, 1990; HANSCHE et al., 1966), Malus sylvestris (L.) Mill. (LABuschagne et al., 2002), and Pistacea vera L. (CHAO and PARFITT, 2003), among others.

Large differences in fertility among clones have been reported in conifer clonal seed orchards (e.g. MERLO and FERNÁNDEZ-LÓPEZ (2004)). Generally, only a fraction of the individuals in a population contribute to much of the 
gamete gene pool and transmit their genes to the progeny generation (GöMÖRY et al., 2000). Failure of synchronization of female flower receptivity and pollen shedding has a negative effect on the gene frequencies in the bulked seed produced in orchards (EL-KASSABY et al., 1988). A lack of synchronization in flowering can lead to non-random cross-fertilization, or to production of a large number of empty seeds (BoEs et al., 1991). Furthermore, quantification of phenological synchronization is fundamental in making decisions about orchard rouging, supplemental mass pollination or controlled pollinations within the orchard (GöMÖRY et al., 2003).

Different techniques have been developed for quantifying the degree of reproductive synchronization between all mating pairs of clones (AsKEW and BLUSH, 1990; GöMÖRY et al., 2003; XIE et al., 1994). The SYNCHRO.SAS programme (intended for SAS -Pc 6.12) has recently been created to facilitate processing of phenological data, as well as for computing several phenological synchronization indices for each female-male combination and for constructing male and female phenograms as well as other simple graphics that may help in the interpretation of phenological synchronization parameters (ZAS et al., 2003).

The phenology of temperate woody plants is commonly assumed to be locally adapted to climate. When the clones in a seed orchard originate from a wide geographic area, different patterns of geographic variation may be revealed for the phenological traits. The geographic variation in individual tree species may reveal an underlying pattern of genetic variation shaped by natural selection under specific geoclimatic conditions, and by other genetic processes. The pattern of genetic variation is typically expressed by correlations between environmental variables and genetic source responses (MORGENSTERN, 1996).

The main objectives of the present study were: 1) to determine the degree of clonal synchronization in a seed orchard and the clonal contribution to the seed crop; 2) to estimate the genetic control in some phenological and production traits; and 3) to discuss the possible effect of the geoclimatic origin of the clone on the results obtained.

\section{Material and Methods}

\section{Material and seed orchard}

The study was carried out with 103 clones of a wild cherry seed orchard, which was established in 1998 at Tui, Pontevedra, Spain ( $42^{\circ} 01^{\prime} \mathrm{N}, 8^{\circ} 40^{\prime} \mathrm{W}, 90 \mathrm{~m}$ asl). The clones were selected for growth and form within natural stands from 7 provenance regions in northern Spain (Figure 1). The seed orchard was planted following a randomized complete block design, with 7 blocks and one-tree plot. The spacing is $3.4 \times 3 \mathrm{~m}$. The climate in the study area is Atlantic, with an annual mean temperature of $14.2^{\circ} \mathrm{C}$, and total annual rainfall of 2503 mm (observation period 1991-2002, Monte Aloia climatic station, $42^{\circ} 04^{\prime} \mathrm{N}, 8^{\circ} 40^{\prime} \mathrm{W}, 400 \mathrm{~m}$ asl).

\section{Assessments}

Flower bud development, total number of flowers (NF) and total number of fruits (NC) were recorded in the seed orchard in 2004 and 2005. The male and female contributions were estimated by the number of flowers counted individually over the whole crown. Six flowering stages were distinguished between the start of flower opening until complete development of the fruit: 1: petals partially opened; 2 : petals completely opened; 3 : some petals have fallen down; 4: all petals have fallen down; 5: small green fruit; 6: standard size green fruit. The most advanced flowering stage $(F)$ of each tree was accepted as its current state, so hereinafter we will refer to this as flowering stage. The flowering stage was monitored 19 times in 2004 (March 1-May 4) and 7 times in 2005 (March 24-April 12).

In a previous study, we related the percentage of male and female fertility to each of the most advanced flowering stages in a tree (Table 1, CASTELO et al. (2006)). This relationship allowed us to study synchronization in the seed orchard. The data were processed with the SYNCHRO.SAS programme (ZAS et al., 2003), by introducing the percentage of female receptivity or the percentage of pollen shedding associated with each phenological score (Table 1) and the date at the start and the end of assessment. The predicted start (START), end (END) and duration (DUR) of female receptivity and

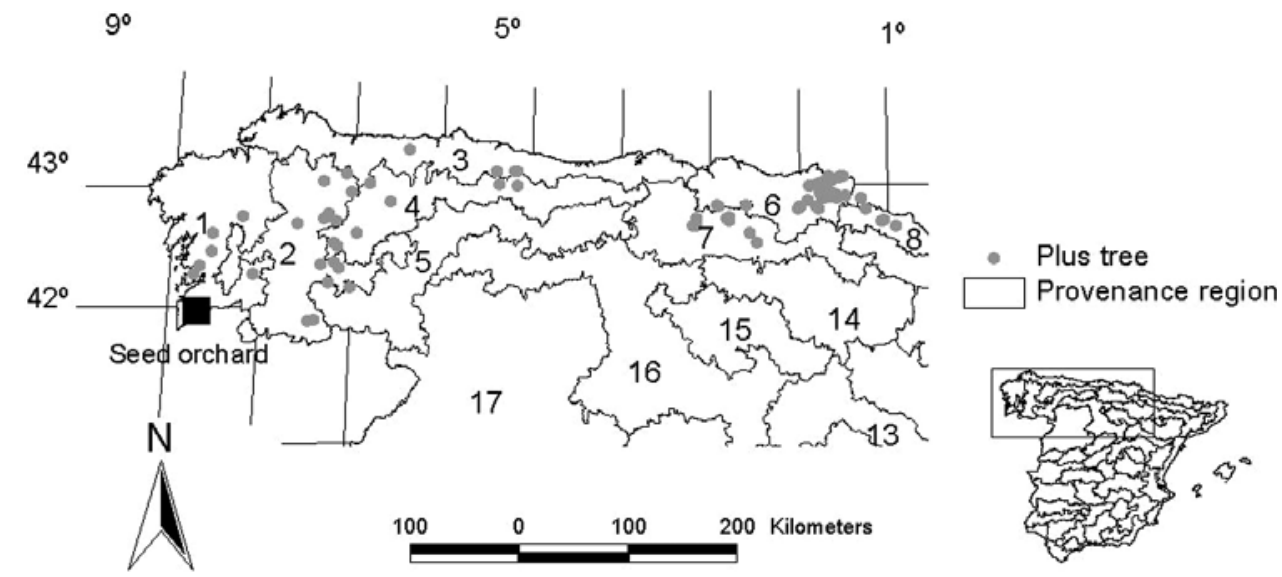

Figure 1. - Location of the plus trees selected in northwest Spain for the seed orchard. Numbers indicate the code of the provenance regions. 
Table 1. - Male and female fertility estimates for a tree corresponding to flowering phenology, measured as the most advanced flowering stage on a tree (F). From: CASTELO et al. (2006).

\begin{tabular}{|c|c|c|}
\hline $\begin{array}{l}\text { Most advanced flowering } \\
\text { stage on a tree }(\mathrm{F})\end{array}$ & $\begin{array}{l}\text { Mate fertility } \\
\qquad(\%)\end{array}$ & $\begin{array}{l}\text { Female lertility } \\
\qquad(\%)\end{array}$ \\
\hline 1: Petals partially opened & 11.5 & 23.0 \\
\hline 2: l'etals completely opened & 33.6 & 41.5 \\
\hline 3: Some petals lave fallen down & 52,2 & 73.2 \\
\hline 4: All petals have fallen down & 38.9 & 55.9 \\
\hline 5: Small green fruit & 21.3 & 31.0 \\
\hline 6. Standard size green fruit & 13.8 & 19.7 \\
\hline
\end{tabular}

pollen shedding were obtained for each clone and for each ramet. START and END were estimated with Julian days (from January 1) and the duration (number of days, DUR) was calculated by subtraction.

Two synchronization indices were calculated on a ramet basis for each pair of clones: i) the male and female phenological overlap between each pair of clones $\left(P O_{i j}\right)$ - taking into account the percentages of female receptivity and pollen shedding throughout the duration of study (Askew and BLUSH, 1990) - and ii) the number of receptive days of clone $i$ during which clone $j$ is shedding pollen $\left(R D_{i j}\right)$ (XIE et al., 1994).

Clonal female contribution was estimated by the number of cherries, and clonal male contribution was estimated, including both number of flowers and $R D_{i j}$ synchronization index (XIE et al., 1994). General clonal contribution for the $i^{\text {th }}$ clone $\left(G_{i}\right)$ in the seed crop was then estimated as follows:

$$
G_{i}=N C_{i} \cdot N F_{i} \cdot \sum_{j-1}^{n} R D_{i j}
$$

The status number of clones in the seed orchard $\left(N_{s}\right)$ (KANG and LindGren, 1998; LINDGREN and Mullin, 1998) was calculated by assuming non-inbred and unrelated clones according to LINDGREN et al. (1996). The formula used was:

$$
N_{s}=\frac{1}{\sum_{i=1}^{n} G_{i}^{2}}
$$

Clonal male and female contributions were classified in a descending order, and the cumulative percentage of contribution was plotted against the proportion of the clones. A graph with the parental-balance curves of the clonal female and male gamete contribution on the seed crop was constructed for each year of study.

\section{Statistical analysis}

Analysis of variance was performed by the GLM procedure (SAS, 1999) with a normal score transformation for $\mathrm{F}$, a square root transformation for $\mathrm{NF}$, and $\log (\mathrm{x}+1)$ transformation for NC. The transformations restored normality and homogeneity of variances to the distributions. To analyse the flowering stage $(F)$, data from the date on which the highest trait variation occurred was used for each year (March 18 in 2004 and March 24 in 2005).

The model used for joint analyses of both years was the following:

$$
\begin{aligned}
X_{m(i j k l)}= & \mu+P_{i}+C(P)_{j(i)}+B_{k}+Y_{l}+P B_{i k}+ \\
& P Y_{i l}+C(P) Y_{j(i) l}+\varepsilon_{m(i j k l)}
\end{aligned}
$$

where $X_{m(i j k l)}$ is the value of the response variable measured on the $m^{\text {th }}$ tree of the $j^{\text {th }}$ clone within the $i^{\text {th }}$ provenance in the $k^{\text {th }}$ block the $l^{\text {th }}$ year, $\mu$ is the overall mean, $P_{i}, C(P)_{j(i)}, B_{k}$ and $Y_{l}$ are the effects of the $i^{\text {th }}$ provenance, the $j^{\text {th }}$ clone within the $i^{\text {th }}$ provenance, the $k^{\text {th }}$ block and the $l^{\text {th }}$ year, respectively; $P B_{i k}$ is the effect of the interaction of the $i^{\text {th }}$ provenance and the $k^{\text {th }}$ block, $P Y_{i l}$ is the effect of the interaction of the $i^{\text {th }}$ provenance and the $l^{\text {th }}$ year, $C(P) Y_{j(i) l}$ is the effect of the interaction between the $j^{\text {th }}$ clone of the $i^{\text {th }}$ provenance and the $l^{\text {th }}$ year, and $\varepsilon_{m(i j k l)}$ is the residual variation that affects the $m^{\text {th }}$ tree of the $j^{\text {th }}$ clone of the $i^{\text {th }}$ provenance in the $k^{\text {th }}$ block the $l^{\text {th }}$ year. All factors were considered random, except year and provenance.

Broad-sense heritability based on clone means $\left(h^{2}{ }_{b s c}\right)$ was estimated according to NANSON (1970):

$$
h_{b \times c}^{2}=\frac{\sigma_{c w_{1}}^{2}}{\sigma_{c, y}^{2}+\sigma_{c(p y}^{2} / y+\sigma_{c}^{2} / n b y}
$$

where $\sigma_{C(P)}^{2}$ is the clonal within provenance variance, $\sigma_{C(P) Y}^{2}$ is the variance of the clonal within provenance by year interaction, and $\sigma_{e}^{2}$ is the residual variance, and $y$, $b$ and $n$ are the number of years, blocks and the harmonic mean of the number of trees per plot, respectively. Standard error of the broad-sense heritability $\left(s e\left(h^{2}{ }_{b s c}\right)\right)$ was estimated as described by LYNCH and WALSH (1998).

The SAS RANDOM statement with the TEST option was used to produce the error mean squares for the mixed-model ANOVA hypothesis tests. This approach requires that a linear combination of mean squares be constructed and $F$ tests with a SATTERTHWAITE (1946) approximation are generated. This approximation may generate fractional degrees of freedom in the denominator and/or negative $\mathrm{F}$ values. Pooling the most non significant mean square into the error term usually produces a traditional positive term.

The Pearson phenotypic correlation coefficients of mean values per clone $\left(r_{p}\right)$ were computed by the SAS 8.0 Proc CORR procedure (SAS, 1999) to determine the extent of relationships between flowering traits.

Geographic (latitude, longitude, altitude and coastal distance) and climatic data (total annual precipitation, minimum monthly summertime precipitation, annual mean temperature, lowest monthly mean temperature, highest monthly mean temperature, whole number of months in which mean minima $<0, \ldots$ ) were determined for each clone. Climatic data was taken from AlluÉ 
(1990). The relationship between flowering traits and the geoclimatic variables in the region of origin was analysed by Pearson correlation on a clone mean basis $\left(r_{P}\right)$.

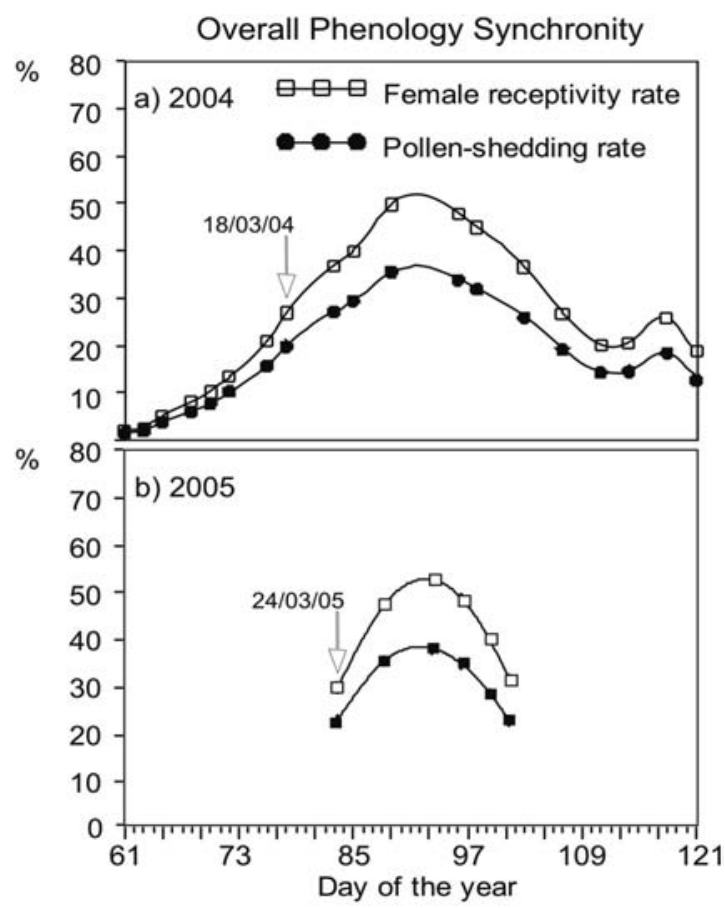

Figure 2. - Overall pollen-shedding and female receptivity rates for 103 Prunus avium clones in the seed orchard under study, in 2004 (a) and 2005 (b). The arrows show the date with the highest trait variation of the flowering stage for each year of study. $\mathrm{N}=721$ trees.

\section{Results}

\section{Overall phenological overlap}

The phenological flowering period started on $1^{\text {st }}$ March and lasted for longer than 60 days in the first year of study (2004) (Figure 2). There was a large variation in start, end and duration of flowering on a tree basis. In 2004 the start of flowering varied between day 61 and 116 (average, day 78.7), the end of flowering varied between day 87 and 125 (average, day 110.4) and the duration of flowering ranged between 9 and 58.5 days (average, 32.1 days) (Table 2). The overall maximum percentage of female receptivity $(51 \%)$ and the maximum pollen release $(33 \%)$ occurred on $4^{\text {th }}$ April in 2004 and 3 days later in 2005 (52\% and $35 \%$ respectively). In general, all the studied clones were quite well synchronized, even though two different maxima of overall phenological overlap were observed in the seed orchard. The two maxima corresponded to two different groups of clones, one formed by clones from populations 4 and 8 , and another formed by the other clones.

\section{Synchronization and clonal contribution}

Synchronization results from data corresponding to the complete flowering period in 2004 are presented here. In this year, reproductive overlap between all pairs of clones was possible in terms of phenology. All clones overlapped with some of the others for at least 1.7 days. The POij values for all the $103 \times 103$ possible pairs of clones ranged between 0.11 and 0.88 . The average length of the flowering overlap in the seed orchard was 22.8 days (Table 2) and the mean flowering overlap index for all pairs of clones was 0.52 . High variability of

Table 2. - Basic statistics, variance components, significance levels and broad-sense heritability estimates $\left(h_{b s c}^{2}\right)$ for some phenological and productive traits measured in single and combined year analyses. Year and provenance region were considered fixed factors.

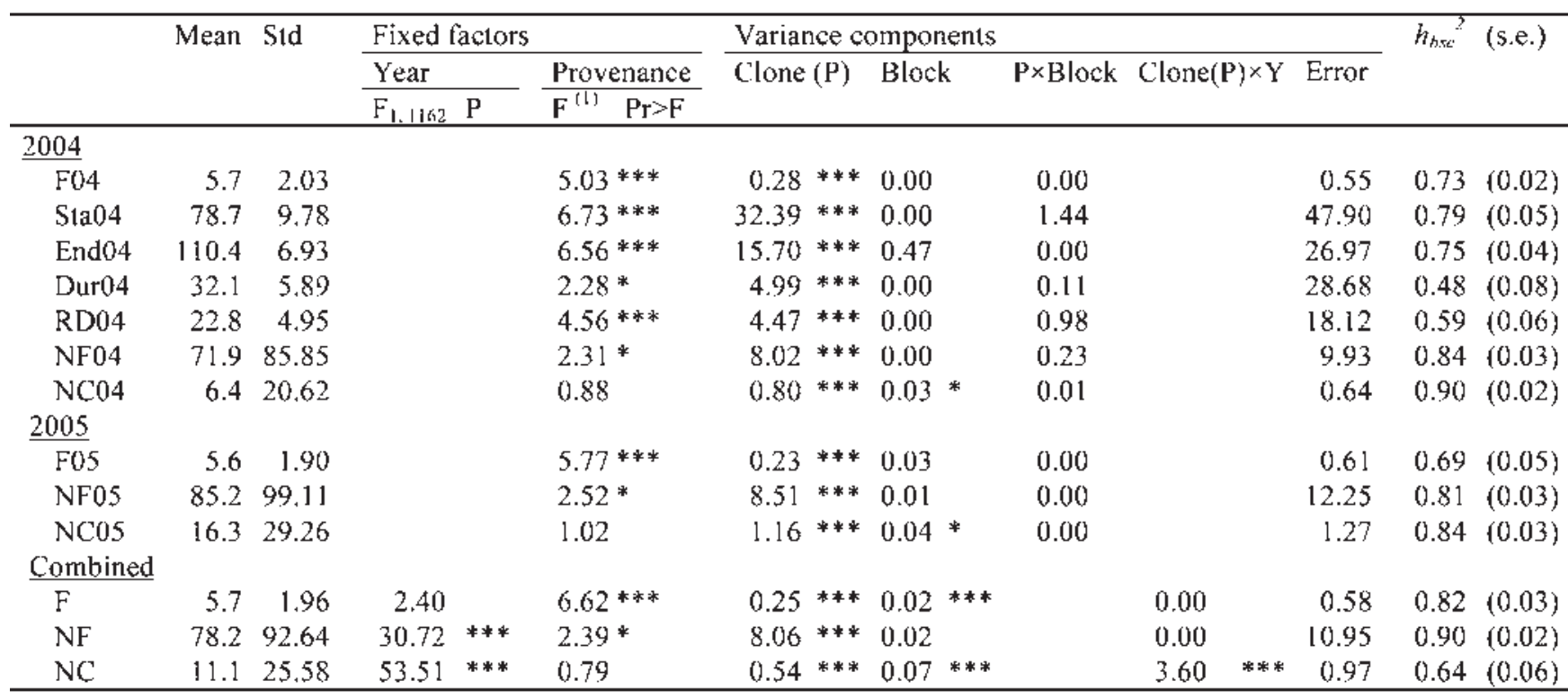

F04, F05 and F are the most developed flowering stage in a specific date in 2004, 2005 and in both years; Sta04, End04, Dur04 and RD04 are the start, end and duration of flowering and the RD synchronization index in 2004; NF04, NF05 and NF are the number of flowers in 2004, 2005 and in both years; NC04, NC05 and NC are the number of cherries in 2004, 2005 and in both years.

Significance levels: $* * *=\mathrm{P}<0.001 ; * *=\mathrm{P}<0.01 ; *=\mathrm{P}<0.05$.

(1) $\mathrm{F}_{6,660}$ for analyses of year $2004, \mathrm{~F}_{6,600}$ for analyses of year 2005 , and $\mathrm{F}_{6,1162}$ for the combined analyses. 

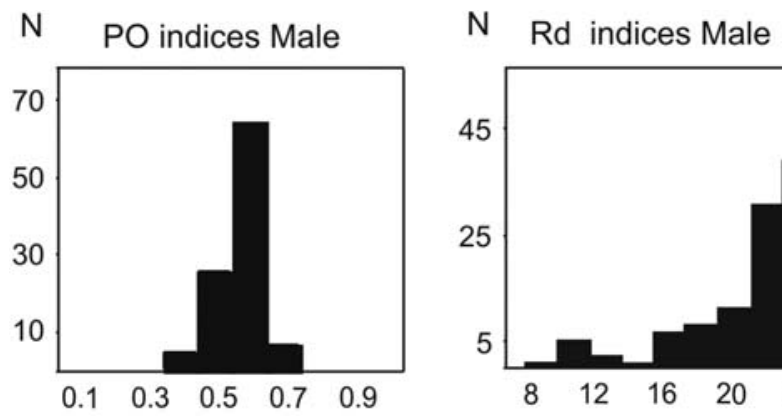

$\mathrm{N} \quad \mathrm{PO}$ indices Female

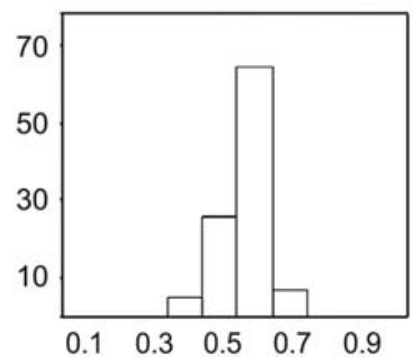

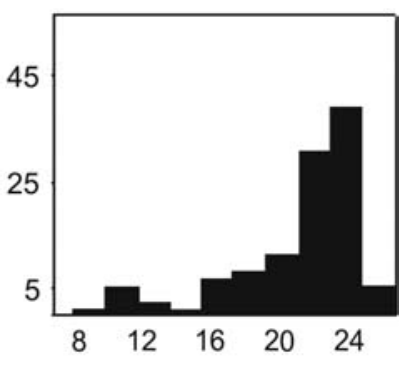

$\mathrm{N}$ Rd indices Female

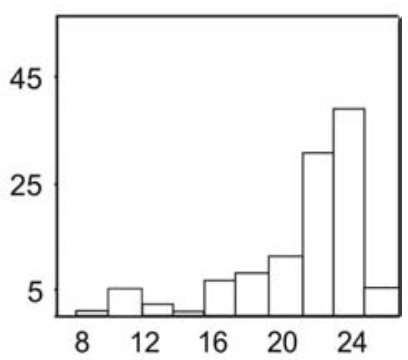

Figure 3. - Male and female frequency histograms estimated for two different overlap indices (POij (AsKew and BLuSH, 1990 ) and $R D i j$ (XIE et al., 1994)) in 2004.

clonal reproductive synchronization index was recognized and very similar male and female flowering overlap on the clonal mean was achieved (Figure 3). The potential outcross efficiency between the early and late clones was low in comparison with clones with intermediate flowering phenology. The POij synchronization indices calculated for pairs of clones from the two latestflowering provenances were higher than the POij values for one clone from these provenances and another from the other provenance regions. The mean number of flowers per tree was 71.9 in 2004 , and 85.2 in 2005. The mean number of cherries per tree was 6.4 and 16.3 in 2004 and 2005, respectively (Table 2). There were large variations in maternal and paternal contributions among clones (Figure 4). The total number of flowers per clone ranged from 1 to 2093, and from 23 to 2918 flowers during the flowering time in 2004 and 2005, respectively. The total number of cherries per clone in the seed

crop oscillated between 0 and around 500 cherries in both years of study. In 2004, $20 \%$ of the clones accounted for $50 \%$ of the male contribution ( $\mathrm{NF} \times \mathrm{RD}$ ). However, only $5 \%$ of the clones accounted for $50 \%$ of the female contribution (NC) (Figure 4a). In 2004, in which cherry success was low, $90 \%$ of the cherry crop was provided by only $25 \%$ of the most productive clones, while $90 \%$ of the potential pollen contribution $(\mathrm{NF} \times \mathrm{RD})$ was provided by $40 \%$ of the most prolifically flowering clones (Figure $4 a$ ). In $2005,90 \%$ of the cherry crop and potential pollen contribution were provided by $50 \%$ and $65 \%$ of the clones, respectively (Figure $4 b$ ). The status number was 48.2 and 64.5 clones in 2004 and 2005, respectively.

\section{Variance components and broad-sense heritability}

There were significant differences among provenances in all traits in each year, except for the number of cherries (Table 2). Two of the seven populations studied (provenances 4 and 8) showed the least advanced flowering stage (on the selected study date) and also the latest initiation and end of flowering period (Figure $5 a, b, c$ ). The shortest duration of flowering and the lowest $R D_{i j}$ overlap index also occurred in these populations (Figure $5 d, e)$.

The clonal within provenance variance was highly significant in all cases $(\mathrm{p}<0.001$, Table 2$)$. Block and provenance by block factors were not significant, except the block for number of cherries (NC) (in both years). The combined analyses revealed the same pattern of variation as in within year analyses (Table 2). The year factor was highly significant for the productive, but not the phenological traits.

Clone within provenance by year interaction was only significant for NC. Nevertheless, it was not high, since $\sigma_{C(P) Y}^{2} / \sigma_{C(P)}^{2}<1$. The broad-sense heritability estimates based on clone means were very high, and varied between 0.69 and 0.90 for all traits, except DUR (0.48) and RD04 (0.59). The values obtained from the combined analysis for $\mathrm{F}$ and $\mathrm{NF}$ were similar to values from year to year analyses, or even higher, which indicates clonal stability between years. However, the broad-sense heritability was lower for $\mathrm{NC}$ (0.64), due to the impact of the clone by year interaction.

\section{a) 2004}

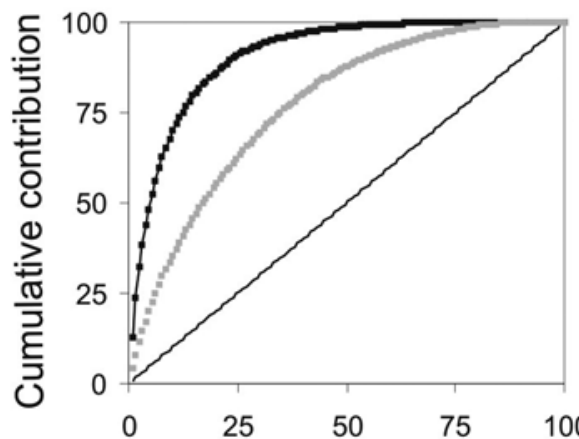

b) 2005

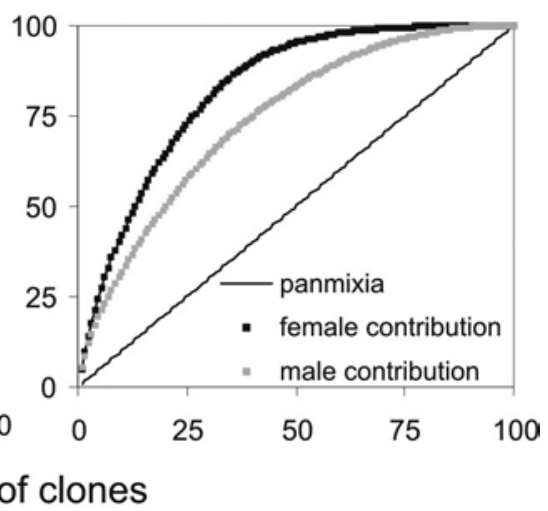

Figure 4. - Parental-balance curves of the clonal female and male gamete contribution on the seed crop of the 103 clones in the clonal seed orchard in: a) 2004, and b) 2005 . 


\section{Correlations among traits}

Pearson correlations $\left(r_{P}\right)$ between different phenological and productive traits are shown in Table 3. The year to year phenotypic correlations $\left(r_{p}\right)$ for flowering stage (F) and number of flowers (NF) were very high and highly significant $(p<0.001)$. For number of cherries (NC) it was moderate and highly significant $(\mathrm{p}<0.001)$. Flowering stage $(\mathrm{F})$ was negatively correlated with initi-
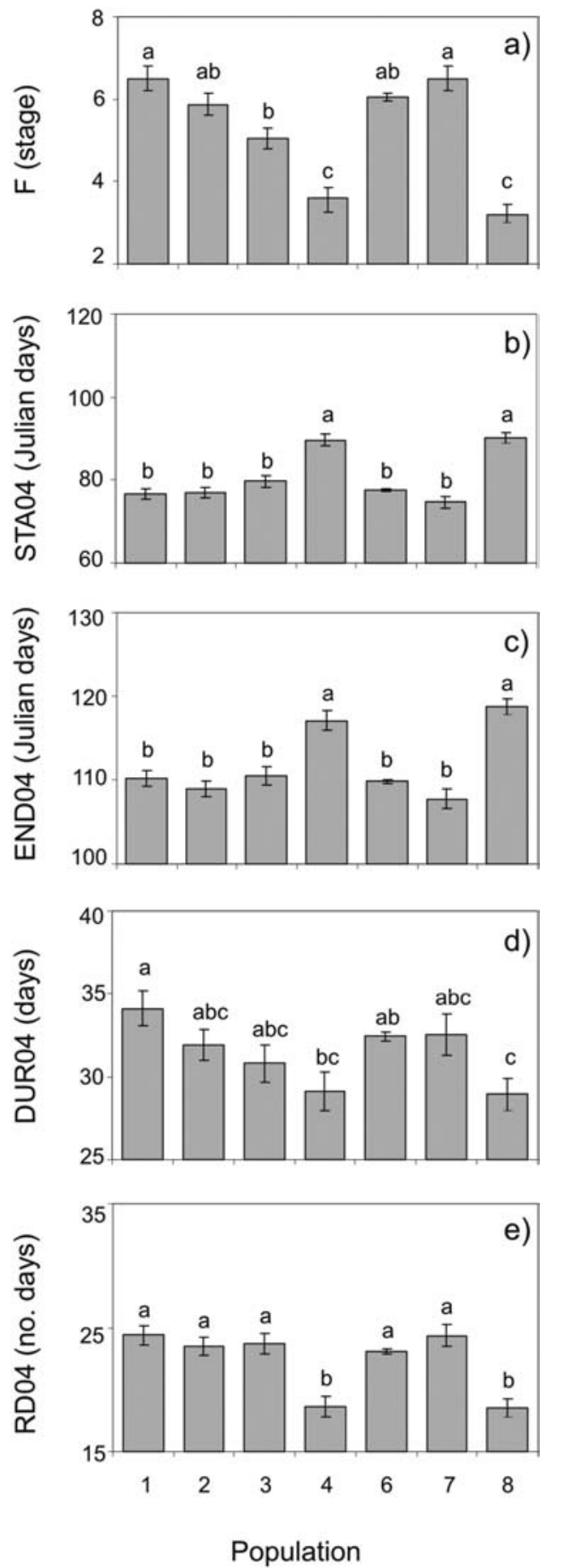

Figure 5. - Differences among provenance regions for the phenological and productive traits, revealed by the Tukey test. Bar graphs show least square mean values (Lsmeans) for the studied population regions and vertical lines represent the standard error. Different letters denote significant differences $(\mathrm{p}<0.05)$. See Table 2 for abbreviations.
Table 3. - Pearson correlation coefficients between the different phenological and productive traits. $\mathrm{N}=103$. Only significant coefficients $(\mathrm{p}<0.05)$ are presented.

F04 Sta04 End04 Dur04 RD04 NF04 NC04 NF05

\begin{tabular}{llllllllll}
\hline Sta04 & -0.90 & & & & & & \\
End04 & -0.83 & 0.90 & & & & & & \\
Dur04 & 0.69 & -0.73 & -0.41 & & & & & \\
RD04 & 0.61 & -0.79 & -0.56 & 0.77 & & & & \\
NF04 & 0.24 & -0.29 & -0.29 & & & & & \\
NC04 & & & & & & 0.62 & & \\
F05 & 0.78 & -0.82 & -0.79 & 0.57 & 0.56 & & & \\
NF05 & & & & & & 0.83 & 0.58 & \\
NC05 & & & & & & 0.63 & 0.49 & 0.69 \\
\hline
\end{tabular}

See Table 2 for abbreviations.

ation and cessation of flowering, but positively correlated with duration. The $R D_{i j}$ index was highly correlated with the other phenological traits $(\mathrm{p}<0.001)$, but not the productive traits $(\mathrm{p}>0.05)$. The productive traits $(\mathrm{NF}$ and NC) were not significantly correlated with any phenological trait, except NF04 with the flowering development in $2004(\mathrm{p}<0.05)$. However, as expected, there were highly significant positive correlations among the productive traits $(\mathrm{p}<0.001)$.

\section{Geographic variation}

Altitude and lowest monthly mean temperature were the geoclimatic parameters that were most closely correlated with the phenological traits (Table 4). Only duration (DUR) showed higher correlations with coastal distance and total annual precipitation. In contrast, the productive traits were not significantly correlated with any geoclimatic data. Flowering stage (F04, F05) and RD04 were highly negatively correlated with altitude, whereas Sta04 and End04 were positively correlated with altitude. Clones originating from areas of high altitude flowered latest and had a lower $R D_{i j}$ synchronization index. Populations 4 and 8, from areas of higher altitude, started and finished flowering later in 2004 (Figure 5). There was a positive correlation between duration (Dur04) and total annual precipitation (P), which indicates that clones from humid areas flowered for longer.

Table 4. - Pearson correlation coefficients between the phenological traits and the geoclimatic parameters at origin. $\mathrm{N}=103$.

\begin{tabular}{lcccc}
\hline & Altitude & $\begin{array}{c}\text { Coastal } \\
\text { distance }\end{array}$ & $\begin{array}{c}\text { Total } \\
\text { precipitatiof }\end{array}$ & $\begin{array}{c}\text { Iowest montly } \\
\text { toean temperatufe }\end{array}$ \\
\hline F04 & $-0.44^{* * *}$ & $-0.32 * * *$ & $0.35 * * *$ & $0.42 * * *$ \\
Sta04 & $0.42 * * *$ & $0.27 * *$ & $-0.26 * *$ & $-0.44 * * *$ \\
End04 & $0.36 * * *$ & $0.21 *$ & $-0.19 *$ & $-0.39 * * *$ \\
Dur04 & $-0.18 *$ & $-0.19 *$ & $0.24 * *$ & $0.19 *$ \\
RD04 & $-0.34 * * *$ & $-0.26 * *$ & $0.20 *$ & $0.39 * * *$ \\
F05 & $-0.38 * * *$ & $-0.25 * *$ & $0.29 * * *$ & $0.39 * * *$ \\
\hline
\end{tabular}

Significance levels: $* * *=\mathrm{P}<0.001 ; * *=\mathrm{P}<0.01 ; *=\mathrm{P}<0.05$. See Table 2 for abbreviations. 


\section{Discussion}

In both years of study, the peak flowering date occurred during the first week of April, one month later than the peak flowering date observed for Prunus mahaleb L. and Prunus spinosa L. in northwest Spain (GUITIÁN et al., 1993).

The number of flowers per tree in the present seed orchard was quite low compared with the density of flowers in cultivars destined for fruit production (LENAHAN and WHITING, 2006). There were three possible reasons for this. Firstly, the studied clones were from plus trees selected for phenotypic vigour and form, not for flower aptitude. Secondly there was little winter chilling, which has been recognized as essential for flower production (HenNessy and ClaYtongreEne, 1995; KozLOWSKI, 1983). The time of pruning can also affect the number of flowers (GUIMOND et al., 1998), and pruning was usually carried out just before bud burst in the seed orchard under study.

The lack of fruit set observed may be associated with several factors, such as winter chilling (BLACK, 1952), pollinators (GUITIÁN et al., 1993), synchronization (HERRERO, 2003) and genetic incompatibility (SCHUELER et al., 2006). Wild cherry needs sufficient accumulated chilling to break winter dormancy (between 550 and 1350 chilling hours, Westwood (1982)). In the seed orchard under study the accumulated chilling hours in 2004 and 2005 (487.7 and 691.8h, respectively) were probably not sufficient for optimal fructification. This factor should probably be taken into account if other $P$. avium seed orchards are planned. The lack of bees observed during the flowering time in the seed orchard is another possible cause of the failure of fructification. Beehives could be placed in the orchard during flowering. The long flowering period observed at the tree level, since flowers and cherries may concur on the same tree on a specific date, along with the high values of the synchronization indices and the lack of correlation between RD04 and the productive traits indicate that synchronization did not cause the lack of fruit set. To ensure the absence of genetic incompatibility for fertilization, molecular markers should be used to determine the putative different groups in the seed orchard in the near future.

The male contribution curve was less distorted than the female contribution curve, which implies that the clonal male contribution (combining flower production and overlapping) is more important than the clonal female contribution (cherry production) in achieving seed crop diversity, especially when the crop success is low (BurczyK and CHALuPKA, 1997). The male clonal contribution achieved on the seed crop (40 and $65 \%$ of the most prolific flowering clones procured $90 \%$ of the potential pollen contribution) is consistent with the clonal contribution obtained in conifer seed orchards, in which $50 \%$ of the best clones produced $80-90 \%$ of flowers of both sexes (BurCzyK and CHALUPKA, 1997; MERLO and FERNÁNDEZ-LóPEZ, 2004). When only cherry production was considered, the status number decreased by $69.3 \%\left(\mathrm{~N}_{\mathrm{s}}=18\right)$ and $28.8 \%\left(\mathrm{~N}_{\mathrm{s}}=46\right)$ in 2004 and 2005, respectively (data not shown). In this study we want to emphasise that inclusion of the male contribution is very important when studying the status number of clones in a seed orchard, especially if the cherry success is low.

The moderate to high genetic control found for the productive traits is consistent with that obtained in almond (Prunus dulcis D.A. Webb) (DiCENTA et al., 1993). The low clone by year interaction value is consistent with the findings of KELLY and SoRK (2002), who indicated that the interannual variability in fructification success in animal-pollinated species is lower than in wind-pollinated species. Moreover, this significant interaction may be due to the intense damage to the fruit crop in 2004, caused by birds. The trees were protected from birds from 2005 onwards to avoid this problem.

The moderate to high genetic control found for the reproductive traits and the null or low clone by year interaction make possible the clonal selection by clonal contribution deployed proportional to its breeding value. In Prunus avium seed orchards it is also very important to include susceptibility to leaf spot caused by the fungus Blumeriella jaapii (Rehm) Arx., which is highly genetically controlled (DíAz et al., 2007). Different management practices, such as selective cherry harvesting or rouging different number of ramets per clone, could be applied to increase the quality and genetic diversity of the seed crop, taking into account clonal contribution, breeding value, and leaf spot susceptibility.

The high genetic control of all phenological traits, except duration, found in the present study, is consistent with other studies of e.g. sweet cherry (HANSCHE et al., 1966), peach (HANSche, 1990), almond (DiCENTA et al., 1993), apricot (CoURANJoU, 1995), apple (LABUSCHAGNE et al., 2002) and pistachio (CHAO and PARFITT, 2003). The moderate genetic control estimated for duration of flowering in the present study was probably overestimated, as only one-year data was used. DicENTA et al. (1993) stated that the inheritance of duration of flowering was very variable and uncertain, since differences in flowering duration are associated with the climatic conditions at the precise moment when a tree flowers. The lack of winter chilling in the seed orchard under study may be the cause of the high value of the clonal mean duration of flowering (32.05 days), since irregular flowering is the result of inadequate winter chilling (CHAO and PARFITT, 2003).

The two maxima found in the overall phenological overlap corresponded to two different groups of clones; one formed by clones from populations 4 and 8 , and another formed by the other clones. Populations 4 and 8 , which originate from areas of high altitude, started and finished flowering later in 2004. The higher temperature in this second peak period probably favoured the shortening of the flowering duration of the clones from these populations (DicENTA et al., 1993). This may explain the highly significant correlation between duration of flowering (DUR04) and the other phenological traits, i.e. the trees that started and finished flowering earlier were those that flowered longest. 
Flowering stage is supposed to be affected by chilling and forcing units, which vary from year to year. DICENTA et al. (1993) studied flowering time in almond trees and found that the year effect was significant. However, the high clonal variation for flowering stage $(\mathrm{F})$ was relatively consistent between years. Data from several years should therefore be used to establish the degree of consistency in yearly variation in flowering.

The high variability in the flowering phenological traits may be a consequence of the wide range of origin of the seed orchard clones. The altitudinal and longitudinal ranges were wide ( 80 to $1200 \mathrm{~m}$ asl. and $0^{\circ} 55^{\prime}$ to $8^{\circ} 44^{\prime} \mathrm{W}$, respectively), but the latitudinal range was rather narrow $\left(42^{\circ} 00^{\prime}\right.$ to $\left.43^{\circ} 27^{\prime} \mathrm{N}\right)$. Altitude was highly correlated with the lowest monthly mean temperature $(-0.94, \mathrm{p}<0.001$, data not shown) and altitudinal and climatic clines (related to low temperature) were found for all the phenological traits studied. Similarly, timing to bud burst has been shown to vary along geographical gradients within the area of distribution of many species (e.g. Fagus sylvatica L. (FALUSI and CALAMASSI, 1997); Ulmus minor Mill. (GHELARDINI et al., 2006); Ulmus laevis Pall., (Whiteley et al., 2003); and Castanea sativa Miller (FERNÁNDEZ-LóPEZ et al., 2005)). Interestingly, there was a significant correlation between flowering phenology (F) and bud burst $\left(r_{P}>0.72\right.$, data not shown) in the same clones used in the study.

The correlation between duration of flowering and lowest monthly mean temperature was much weaker, since the former is much more affected by the interannual climatic conditions. Other flowering traits such as flower size, pulp and seed mass were negatively correlated with altitude in Prunus mahaleb, and climatic conditions accounted for most of the observed variation in flower and fruit characteristics (KoLLMANN and PFLUGSHAUPT, 2001).

\section{Conclusions}

The overall synchronization in the seed orchard under study was good, although two different groups of clones were observed. Large variations in maternal and paternal contributions among clones were observed. The inclusion of the male contribution of clones in the seed orchard increases the accuracy of estimation of the status number, especially if only a small number of cherries are produced. Breeders should consider the use of this method for accurate estimation of the effective population number.

There was considerable genetic variation in flowering and productive traits among the $P$. avium clones studied. The moderate to high broad-sense heritability estimates suggest that such traits should be included in the selection of productive populations in the Galician breeding programme.

The pattern of geographic variation in phenological traits was related to altitude. A pattern of climatic variation in the traits was also observed and related to low temperatures. These findings suggest that clones from high altitudes and low temperatures tend to flower later and have a lower synchronization $R D_{i j}$ index. However, no cline was observed for the productive traits.

\section{Acknowledgements}

The authors gratefully thank JoRge RodRíguez, PABLO CASTELO and RICARDO FERRADÁs for their assistance in assessment of the trials. R. DÍAZ was funded by an 'INIACCAA' postdoctoral fellowship. The study was partially financed by INIA project RTA05-57-C05-03.

\section{References}

Allué, J. L. (1990): Atlas fitoclimático de España. Taxonomías. INIA. Ministerio de Agricultura, Pesca y Alimentación, Madrid, $221 \mathrm{p}$.

Askew, G. R. and T. D. Blush (1990): An index of phenological overlap in flowering for clonal conifer seed orchards - Short note. Silvae Genet. 39(3-4): 168-171.

BLACK, M. W. (1952): The problem of prolonged rest in deciduous fruit trees. Proceedings of the $13^{\text {th }}$ International Horticultural Congress, London, p. 1122-1131.

Boes, T. K., J. R. BRANDLE and W. R. LovetT (1991): Characterization of flowering phenology and deed yield in a Pinus sylvestris clonal seed orchard in Nebraska. Can. J. For. Res. 21(12): 1721-1729.

BuRCZYK, J. and W. CHALuPKA (1997): Flowering and cone production variability and its effect on parental balance in a Scots pine clonal seed orchard. Ann. Sci. For. 54(2): 129-144.

Castelo, P., E. Merlo, R. Díaz and Fernández-LóPez, J.: Wild cherry reproductive phenology. Proceedings of the Population Genetics and Genomics of Forest Trees: From Gene Function to Evolutionary Dynamics and Conservation, Alcalá de Henares, Madrid (Spain), p. 170-171 (2006).

Chao, C. T. and D. E. PARfitt (2003): Genetic analyses of phenological traits of pistachio (Pistacia vera L.). Euphytica 129(3): 345-349.

Couranjou, J. (1995): Genetic studies of 11 quantitative characters in apricot. Sci. Hortic. 61(1-2): 61-75.

DíAz, R., R. ZAS and J. FERNÁNDEZ-LÓPEZ (2007): Genetic variation of Prunus avium in susceptibility to cherry leaf spot (Blumeriella jaapii) in spatially heterogeneous infected seed orchards. Ann. For. Sci. 64: 21-30.

Dicenta, F., J. E. Garcia and E. A. Carbonell (1993): Heritability of flowering, productivity and maturity in almond. J. Horticult. Sci. 68(1): 113-120.

El-Kassaby, Y. A., K. Ritland, A. M. K. Fashler and W. J. B. DEvitT (1988): The role of reproductive phenology upon the mating system of a Douglas-fir seed orchard. Silvae Genet. 37(2): 76-82.

FAlusi, M. and R. CAlamassi (1997): Bud dormancy in Fagus sylvatica L. I. Chilling and photoperiod as factors determining budbreak. Plant Biosystems 131(1): 67-72.

FERNÁNDEZ-LóPEZ, J., R. ZAS, R. Blanco-Silva and R. DíAZ (2005): Geographic differentiation in adaptative traits of wild chestnut Spanish populations (Castanea sativa Miller). Invest. Agr.: Sist. Rec. For. 14(1): 13-26.

Ghelardini, L., M. FAlusi and A. SANTINI (2006): Variation in timing of bud-burst of Ulmus minor clones from different geographical origins. Can. J. For. Res. 36(8): 1982-1991.

GömöRy, D., R. BRuchaniK and R. LONGAUER (2003): Fertility variation and flowering asynchrony in Pinus sylvestris: consequences for the genetic structure of progeny in seed orchards. For. Ecol. Manage. 174(1-3): $117-126$. 
GÖMÖRY, D., R. BRUChANIK and L. PAUlE (2000): Effective population number estimation of three Scots pine (Pinus sylvestris L.) seed orchards based on an integrated assessment of flowering, floral phenology, and seed orchard design. Forest Genet. 7(1): 65-75.

Guimond, C. M., G. A. LANG and P. K. AndRews (1998): Timing and severity of summer pruning affects flower initiation and shoot regrowth in sweet cherry. Hortscience 33(4): 647-649.

Guitián, J., P. Guitián and J. M. SANChez (1993): Reproductive biology of two Prunus species (Rosaceae) in the Northwest Iberian peninsula. Plant Syst. Evol. 185 (3-4): 153-165.

Hansche, P. E. (1990): Heritability of spring bloom and fall leaf abscission dates in Prunus persica. Hortscience 25(12): 1639-1641.

Hansche, P. E., V. Beres and R. M. Brooks (1966): Heritability and genetic correlation in sweet cherry. P. Am. Soc. Hortic. Sci. 88(JUN): 173-183.

Hennessy, K. J. and K. Claytongreene (1995): Greenhouse Warming and Vernalization of High-Chill Fruit in Southern Australia. Climatic Change 30(3): 327-348.

HERRERO, M. (2003): Male and female synchrony and the regulation of mating in flowering plants. Philos. Trans. R. Soc. Lond. Ser. B 358(1434): 1019-1024.

KANG, K. S. and D. LINDGREN (1998): Fertility variation and its effect on the relatedness of seeds in Pinus densiflora, Pinus thunbergii and Pinus koraiensis clonal seed orchards. Silvae Genet. 47(4): 196-201.

Kelly, D. and V. L. SoRK (2002): Mast seeding in perennial plants: Why, how, where? Ann. Rev. Ecol. Syst. 33: 427-447.

KoBliha, J. (2002): Wild cherry (Prunus avium L.) breeding program aimed at the use of this tree in the Czech forestry. J. For. Sci. 48(5): 202-218.

Kollmann, J. and K. Pflugshaupt (2001): Flower and fruit characteristics in small and isolated populations of a fleshy-fruited shrub. Plant Biol. 3(1): 62-71.

KOZLOWSKI, T. T. (1983): Reduction in yield of forest and fruit trees by water and temperature stress, pp. 67-88. In: Crop reactions to water and temperature stresses in humid, temperate climates, edited by RAPER, C. D., Kramer, P. J., Westview, Colorado, USA.

Labuschagne, I. F., J. H. Louw, K. Schmidt and A. Sadie (2002): Genetic variation in chilling requirement in apple progeny. J. Am. Soc. Hortic. Sci. 127(4): 663-672.
Lenahan, O. M. and M. D. Whiting (2006): Fish oil plus lime sulfur shows potential as a sweet cherry postbloom thinning agent. Hortscience 41(3): 860-861.

LindGren, D., L. GEA and P. JEFFERSON (1996): Loss of genetic diversity monitored by status number. Silvae Genet. 45(1): 52-59.

LindGRen, D. and T. J. Mullin (1998): Relatedness and status number in seed orchard crops. Can. J. For. Res. 28(2): 276-283.

LYNCH, M. and B. WALSH (1998): Genetics and analysis of quantitative traits. Sinauer Associates Inc., Sunderland, $979 \mathrm{p}$.

Merlo, E. and J. Fernández-LóPez (2004): Análisis del balance parental reproductivo en un huerto semillero de Pinus pinaster. Invest. Agr. Sist. Rec. For. 13(2): 387-398.

MoRgenstern, E. K. (1996): Geographic variation in forest trees: genetic basis and application of knowledge in silviculture. UBC Press, Vancouver, British Columbia, $209 \mathrm{p}$.

Nanson, A. (1970): L'héritabilité et le gain d'origine génétique dans quelques types d'expérience. Silvae Genet. 19(4): 113-121.

SAS (1999): Getting started with the SAS System, Version 8. SAS Institute Inc., Cary, NC, $90 \mathrm{p}$.

SATterthwaite, F. E. (1946): An approximate distribution of estimates of variance components. Biometrics Bull. 2(6): 110-114.

Schueler, S., A. Tusch and F. Scholz (2006): Comparative analysis of the within-population genetic structure in wild cherry (Prunus avium L.) at the self-incompatibility locus and nuclear microsatellites. Mol. Ecol. 15(11): 3231-3243.

Westwood, N. H. (1982): Fruticultura de zonas templadas. Mundi-Prensa, Madrid, $461 \mathrm{p}$.

Whiteley, R. E., S. BlaCK-SAMUELSSON and G. JANSSON (2003): Within and between population variation in adaptive traits in Ulmus laevis Pall., the European white elm. Forest Genet. 10(4): 313-323.

XIE, C. Y., J. WoodS and M. STOEHR (1994): Effects of seed orchard inputs on estimating effective population size of seedlots - a computer simulation. Silvae Genet. 43(2-3): 145-154.

ZAS, R., E. MERLO and J. FERnÁNDEZ-LóPEZ (2003): SYNCHRO: A SAS program for analysing the floral phenological synchronisation in seed orchards. Silvae Genet. 52(5-6): 212-215. 